\title{
Allergy to beer - case report
}

\author{
Natalia Ukleja-Sokolowska,, Ewa Gawronska-Ukleja, Magdalena Zbikowska-Gotz, Zbigniew Bartuzi
}

From Food Allergy and Anaphylaxis Meeting 2014

Dublin, Ireland. 9-11 October 2014

\section{Introduction}

Beer is made mainly from barley, hops and yeast. Each of these ingredients may be the source of hypersensitivity.

\section{Material and methods}

Patient, male, 50 years old, treated in the Outpatient Clinic of Allergic Diseases because of bronchial asthma. On a follow up visit patient was complaining of watery rhinorrhea, swelling and itching of hands and feet, generalized urticaria. Careful interview reveled that patient usually drinks a beer in the afternoon and symptoms worsen immediately after ingestion. During diagnosis patient had skin prick test (SPT) with inhalatory and food allergensusing a set from Allergopharma. We also determined the level of allergen specific IgE against Dermatophagides pteronissinus and Dermatophagoides farine, Alternata alternata, Cladosporium, Aspergillus, Hops and Barley. Patient had prick by prick test with three brands of beer, fresh and dried hops, baking yeast, barley and hopped liquid malt extract.

\section{Results}

Patient had positive SPT for D. pteronissinus $8 \mathrm{~mm}$, D. farinae $5 \mathrm{~mm}$. Eleveted level of asIgE against Alternaria in II class $(1.6 \mathrm{kU} / \mathrm{ml})$. Prick by prick test with three brands of beer were positive (I - 7mm, II $-8 \mathrm{~mm}$, III $-4 \mathrm{~mm}$ ). Prick test with hopped liquid malt extract was also positive $-6 \mathrm{~mm}$ and native hops: dried $-7 \mathrm{~mm}$ and fresh $-8 \mathrm{~mm}$. The level of asIgE against barley and hops was not elevated.

\section{Conclusion}

The patient was diagnosed with allergy to beer ingredients and was recommended to exclude it from the diet. Patients condition improved, skin lesions completely disappeared. Attempts of beer consumption were

Clinic of Allergy, Clinical Immunology and Internal Diseases, Collegium Medicum, UMK, Bydgoszcz, Poland

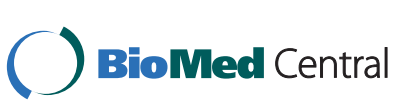

(c) 2015 Ukleja-Sokolowska et al; licensee BioMed Central Ltd. This is an Open Access article distributed under the terms of the Creative Commons Attribution License (http://creativecommons.org/licenses/by/4.0), which permits unrestricted use, distribution, and reproduction in any medium, provided the original work is properly cited. The Creative Commons Public Domain Dedication waiver (http://creativecommons.org/publicdomain/zero/1.0/) applies to the data made available in this article, unless otherwise stated. followed with recurrence of symptoms within $30 \mathrm{~min}$ utes of ingestion.

\section{Consent}

Written informed consent was obtained from the patient for publication of this abstract and any accompanying images. A copy of the written consent is available for review by the Editor of this journal.

Published: 30 March 2015

doi:10.1186/2045-7022-5-S3-P62

Cite this article as: Ukleja-Sokolowska et al:: Allergy to beer - case

report. Clinical and Translational Allergy 2015 5(Suppl 3):P62.
Submit your next manuscript to BioMed Central and take full advantage of:

- Convenient online submission

- Thorough peer review

- No space constraints or color figure charges

- Immediate publication on acceptance

- Inclusion in PubMed, CAS, Scopus and Google Scholar

- Research which is freely available for redistribution Submit your manuscript at
www.biomedcentral.com/submit C Biomed Central 